\title{
Pengaruh Penguasaan Kosakata dan Minat Belajar terhadap Kemampuan Menulis Teks Deskripsi (Survei pada MTs Swasta di Jakarta Selatan)
}

\author{
Taufiqurrohman ${ }^{1)}$ \\ Universitas Indraprasta PGRI \\ Jalan Nangka No. 58 C/TB. Simatupang, Tanjung Barat, Jakarta Selatan 12530 \\ Hasbullah ${ }^{2)}$ \\ Universitas Indraprasta PGRI \\ Jalan Nangka No. 58 C/TB. Simatupang, Tanjung Barat, Jakarta Selatan 12530 \\ aafiqkasta@gmail.com ${ }^{1)}$

\begin{abstract}
The Goal of this research is to understand the effects ofmastery vocabulary andinterest in learning on the ability to write a descriptive text. This research uses the regression survey method with senior high school students as it's population and through proposional random sampling the data that has been accumulated consist of 88 students. The regression technique is used to analyze data using an aplication called SPSS 24. The results of this resarch has proven that there is a significant indirect effect of mastery vocabulary andinterest in learning on the ability to write a descriptive text..
\end{abstract}

Keywords: interest in learning, mastery vocabulary, the ability to write a descriptive text.

\begin{abstract}
Abstrak
Penelitian ini bertujuan mengetahui pengaruh penguasaan kosakata dan minat belajar terhadap Kemampuan Menulis Teks Deskripsi. Penelitian mempergunakan survei dengan analisis regresi sebagai populasi siswa MTs Swasta di Jakarta Selatan, melalui teknik sampling acak proporsional diperoleh sampel sebesar 88 siswa. Teknik regresi digunakan untuk analisis data dengan menggunakan program aplikasi SPSS 24. Hasil penelitian membuktikan bahwa terdapat pengaruh yang signifikan penguasaan kosakata dan Minat Belajar terhadap Kemampuan Menulis Teks Deskripsi.
\end{abstract}

Kata Kunci: minat belajar, penguasaan kosakata, kemampuan menulis teks deskriptif

\section{PENDAHULUAN}

Menurut Kridalaksana (2008:137), kosakata (vocabulary) adalah kumpulan kata; khazanah kata; leksikon. Dengan demikian, seseorang yang akan berbicara atau menulis seharusnya memiliki sejumlah kata. Semakin banyak jumlah kata yang dimiliki oleh seseorang, maka seseorang akan semakin mudah untuk menyusun kalimat, baik dalam bentuk bahasa lisan maupun bahasa tulis. Semakin banyak kosakata yang dimiliki, semakin besar pula kemungkinan seseorang untuk terampil berbahasa.

Hal senada dijelaskan oleh Nurgiyantoro (2001:213) yang mengemukakan bahwa penguasaan kosakata dapat dibedakan ke dalam penguasaan yang bersifat

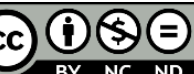

Creative Commons Attribution-NonCommercial-NoDerivatives 4.0 International License 
reseptif dan produktif. Kemampuan memahami kosakata terlihat dalam kegiatan membaca dan menyimak, sedang kemampuan mempergunakan kosakata tampak dalam kegiatan menulis dan berbicara. Yang dimaksud dengan kata-kata aktif adalah kata-kata yang sering dipergunakan seseorang dalam berbicara atau menulis. Kata-kata pasif adalah kata yang hampir tidak dapat digunakan oleh seseorang, tetapi akan menimbulkan reaksi bahasa bila didengar atau dibaca. Dari penjelasan di atas dapat disimpulkan bahwa penguasaan kosakata dapat dimiliki secara aktif dan pasif. Penguasaan kosakata merupakan modal dasar dalam belajar teks narasi dan penting untuk dikuasai, karena tanpa penguasaan kosakata tidak mungkin orang bisa menulis dengan baik dan benar. Dengan penguasaan kosakata yang cukup maka komunikasi akan terjadi dengan baik dan dapat mengurangi kesalah pahaman terutama dalam berkomunikasi dengan menggunakan tulisan.

Kosakata merupakan salah satu hal yang penting ketika kita berkomunikasi menggunakan bahasa. Seseorang dapat memahami ide, gagasan, ataupun pendapat dari kata-kata yang kita gunakan dalam penyampaiannya. Tanpa kosakata yang memadai, maka seseorang akan mengalami kesulitan dalam berkomunikasi. Banyak definisi kosakata yang dikemukakan para ahli bahasa. Pendapat ahli yang satu dengan yang lainnya mungkin berbeda, tetapi banyak pula persamaannya.

Suryabrata (1993: 109) bahwa minat adalah kecenderungan dalam diri individu untuk tertarik pada suatu objek atau menyenangi suatu objek. Sardiman (2007:75) mengemukakam bawhwa minat dapat juga dikatakan sebagai serangkaian usaha yang dikakukan seseorang untuk menyediakan kondisi-kondisi tertentu, sehingga seseorang mau dan ingin melakukan sesuatu, dan bila ia tidak suka maka akan berusaha meniadakan atau mengelakkan perasaan tidak suka itu. Minat adalah suatu keadaan dimana sesorang mempunyai rasa ketertarikan akan sesuatu, seperti yang diungkapkan oleh Suryabrata (1993: 109) bahwa minat adalah kecenderungan dalam diri individu untuk tertarik pada suatu objek atau menyenangi suatu objek.

Minat muncul karena adanya rasa ketertarikan untuk mengetahui atau mempelajari sesuatu. Dalam artian minat timbul karena adanya kesadaran dalam diri sendiri untuk menerima hubungan antara dirinya sendiri dengan suatu hal diluar dirinya. Sama halnya dengan minat baca, minat untuk membaca tidak bisa muncul jika tidak ada rasa ketertarikan.

Sardiman (2007:89) mengemukakan dilihat dari dasar pembentukannya, minat ada dua macam yaitu minat intrinsik dan ekstrinsik. Minat intrinsik adalah motif-motif yang akanmenjadi aktif atau berfungsinya tidak perlu dirangsang dari luar karena dalam diri individu sudah ada dorongan untuk melakukan sesuatu. Sebagai contoh seseorang yang senang membaca, tidak usah menyuruh atau mendorongnya dia sudah rajin mencari buku untuk dibaca.

Minat ektrinsik adalah motif-motif suasana yang menyenangkan dan mempertinggi gairah belajar serta sekaligus untuk membangkitkan harga diri. Selain itu, hukuman dapat juga digunakan sebagai reinforcement yang negatif, tetapi kalau diberikan secara tepat dan bijak bisa menjadi alat motivasi, sedangkan bentuk reinforcement yang lain adalah hadiah. Hadiah dapat dikatakan sebagai minat, tetapi tidak selalu demikian, dalam pemberian hadiah juga tepat waktu dan sesuai dengan kebutuhan anak. 
Terjadinya proses kegiatan belajar dalam ranah afektif dapat diketahui dari tingkah laku murid yang menunjukkan adanya kesenangan belajar. Perasaan, emosi, minat, sikap dan apresiasi yang positif menimbulkan tingkah laku yang konstruktif dalam diri pelajar. Perasaan mengontrol tingkah laku, sedangkan pikiran (kognisi) tidak. Perasaan dan emosi mempunyai peran utama dalam menghalangi atau mendorong belajar. Oleh karena itu, perkembangan afektif seperti halnya perkembangan kognitif perlu memperoleh penekanan dalam proses belajar. Keterampilan menulis merupakan salah satu jenis keterampilan berbahasa yang harus dikuasai siswa. Keterampilan menulis merupakan perwujudan bentuk komunikasi secara tidak langsung, tidak langsung bertatap muka dengan orang lain. Menulis merupakan suatu kegiatan yang produktif dan ekspresif. Memang pada kenyataannya menulis merupakan keterampilan yang dapat dikatakan lebih sulit daripada keterampilan berbahasa yang lain, seperti menyimak, membaca dan berbicara. Dalam proses menulis, dituntut agar memperhatikan struktur yang berkaitan dengan unsur-unsur tulisan agar pembaca dapat memahami pesan yang ingin disampaikan oleh penulis. Oleh karena itu, penulis harus benar-benar menggunakan atau memakai struktur sebuah tulisan seperti kata, kalimat, paragraf, dan lain-lain dengan baik.

Menurut (Rofi'uddin dan Zuhdi, 1999:159), keterampilan menulis merupakan suatu keterampilan menuangkan pikiran, gagasan, pendapat tentang sesuatu, tanggapan terhadap suatu pernyataan keinginan, atau pengungkapan perasaan dengan menggunakan bahas tulis. Menurut Tarigan (2008: 83), keterampilan menulis adalah salah satu keterampilan berbahasa yang produktif dan ekspresif yang dipergunakan untuk berkomunikasi secara tidak langsung dan tidak secara tatap muka dengan pihak lain.

Menurut Tarigan (2008: 2), menulis ialah menurunkan lambang-lambang atau grafik yang menggambarkan suatu bahasa yang dipahami oleh seseorang sehingga seseorang atau orang lain dapat membaca lambang-lambang grafik itu. Menulis merupakan kegiatan menuangkan pikiran dan ide-ide melalui tulisan dengan tujuan tertentu. Menurut Tarigan (2008:3), "menulis merupakan keterampilan berbahasa yang dipergunakan untuk berkomunikasi secara tidak langsung, tidak secara tatap muka dengan orang lain". Menulis merupakan kegiatan yang produktif dan ekspresif. Menulis merupakan satu kegiatan yang diperlukan di era modern seperti ini. Kemampuan menulis bisa dikatakan sebagai satu ciri dari orang yang terpelajar atau bangsa yang terpelajar.Kata'menulis' secara morfologis diturunkan dari dasar kata "tulis' kemudian melalui proses afiksasi dengan morfem meN- yang artinya 'melakukan kegiatan seperti yang dimaksud pada dasar katanya'.

Kata deskripsi berasal dari bahasa latin, yaitu describere yang berarti menulis tentang, membeberkan (memerikan), melukiskan sesuatu hal. Dalam bahasa Inggris adalah description yang tentu saja berhubungan dengan kata kerja to describe (melukiskan dengan bahasa) (Finozza, 2009: 239-240). Dalam kamus bahasa Inggris kata deskripsi; menggambarkan, membuat; sedangkan description yakni gambaran; lukisan. Describe lebih mengarah kepada penjelasan sebagai kata kerja, sedangkan description lebih sebagai kata benda.

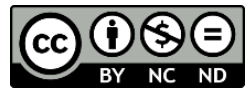


Berdasarkan pemaparan di atas, maka dalam penelitian ini dapat dirumuskan permasalahannya adalah bagaimana pengaruh penguasaan kosakata dan minat belajar terhadap kemampuan menulis teks deskripsi.

\section{METODE}

Penelitian ini merupakan penelitian kuantitatif dengan menggunakan metode survei dan dilaksanakan di Kota Bogor dengan populasi sejumlah 762 siswa MTs sebagai objek penelitian. Sampel diambil acak dari setiap sekolah di tiga sekolah, yaitu MTs Al-Makmur Jakarta Selatan, MTs Al-Mawaddah Jakarta Selatan, dan MTs Daarussa'adah Jakarta Selatan. Jumlah sampel adalah 88 responden. Variabel penelitian ini yaitu variabel terikat (dependent variable) adalah kemampuan menulis teks deskripsi (Y) dan variabel bebas (independent variable ) adalah minat belajar (X1), danpenguasaan kosakata (X2). Pada penelitian ini desain penelitian yang digunakan adalah analisis regresi, yaitu mencari hubungan dan pengaruh antara dua variabel bebas dan satu variabel terikat. Metode ini memberikan gambaran tentang variabel-variabel yang ditemukan sekaligus menyelidiki hubungan dan pengaruh antara variabel. Oleh karena itu, metode ini akan mengungkapkan data faktual berdasarkan informasi yang ditemukan.

Data terkait variabel dalam penelitian ini diperoleh dengan cara menyebar kuesioner/angket dengan 30 butir soal pernyataan. Skor kuesioner dijadikan dasar dalam penghitungan melalui SPSS.

\section{HASIL DAN PEMBAHASAN}

\section{Hasil}

Penelitian dilakukan pada 85 siswa kelas XI MTs Swasta di Jakarta Selatan. Penelitian ini terdiri dari tiga variabel, yaitu Minat Belajar $\left(\mathrm{X}_{1}\right)$, penguasaan kosakata $\left(\mathrm{X}_{2}\right)$, dan Kemampuan Menulis Teks Deskripsi (Y). Deskripsi hasil penelitian disajikan berupa variabilitas dari ketiga variabel yang mencakup skor tertinggi, skor rendah, simpangan baku, modus, median dan sebaran data, sebagai dasaruntuk pembahasan selanjutnya. Berdasarkan perhitungan dengan bantuan SPSS 24.0 diperoleh hasil pengolahan data sebagai berikut:

\section{Tabel 1. Perhitungan Koefisien Korelasi Ganda}

\begin{tabular}{|c|c|c|c|c|}
\hline \multicolumn{5}{|c|}{ Model Summary } \\
\hline Model & $\mathrm{R}$ & R Square & $\begin{array}{l}\text { Adjusted R } \\
\text { Square }\end{array}$ & $\begin{array}{l}\text { Std. Error of the } \\
\text { Estimate }\end{array}$ \\
\hline 1 & $.563^{\mathrm{a}}$ & .317 & .301 & 6.806 \\
\hline
\end{tabular}

a. Predictors: (Constant), Minat Belajar, Penguasaan Kosakata 
Tabel 2. Hasil Perhitungan Persamaan Garis Regresi Pengaruh Variabel $\mathrm{X}_{1}$ dan $\mathrm{X}_{2}$ terhadap Variabel Y (ANOVA $\left.{ }^{\mathrm{a}}\right)$

\begin{tabular}{rlrrrrr}
\multicolumn{7}{c}{ ANOVA $^{\mathbf{a}}$} \\
\hline & Model & Sum of Squares & df & Mean Square & F & \multicolumn{1}{c}{ Sig. } \\
\hline & Regression & 1824.262 & 2 & 912.131 & 19.694 & $.000^{\mathrm{b}}$ \\
1 & Residual & 3936.818 & 85 & 46.316 & & \\
& Total & 5761.080 & 87 & & & \\
\hline
\end{tabular}

a. Dependent Variable: Kemampuan Menulis Teks Deskripsi

b. Predictors: (Constant), Minat Membaca, Penguasaan Kosakata

Tabel 3. Hasil Perhitungan Pengujian Signifikasi Koefisien Regresi Pengaruh Variabel $X_{1}$ dan $X_{2}$ dengan Variabel $Y$

\begin{tabular}{|c|c|c|c|c|c|c|}
\hline & \multicolumn{6}{|c|}{ Coefficients $^{\mathrm{a}}$} \\
\hline & \multirow[t]{2}{*}{ Model } & \multicolumn{2}{|c|}{$\begin{array}{l}\text { Unstandardized } \\
\text { Coefficients }\end{array}$} & \multirow{2}{*}{$\begin{array}{r}\text { Standardized } \\
\text { Coefficients } \\
\text { Beta } \\
\end{array}$} & \multirow[t]{2}{*}{$\mathrm{t}$} & \multirow[t]{2}{*}{ Sig. } \\
\hline & & $\mathrm{B}$ & Std. Error & & & \\
\hline \multirow{3}{*}{1} & (Constant) & 18.757 & 9.727 & & 1.928 & .057 \\
\hline & Penguasaan Kosakata & .236 & .098 & .232 & 2.408 & .018 \\
\hline & Minat Belajar & .402 & .089 & .434 & 4.503 & .000 \\
\hline
\end{tabular}

a. Dependent Variable: Kemampuan Menulis Teks Deskripsi

\section{Pembahasan}

Dari perhitungan pada tabel 1. di atas di peroleh bahwa koefisien korelasi tersebut signifikan, dengan kata lain bahwa terdapat pengaruh yang signifikan variabel bebas penguasaan kosakata $\left(\mathrm{X}_{1}\right)$ minat belajar $\left(\mathrm{X}_{2}\right)$ secara bersama-sama terhadap kemampuan menulis teks deskripsi (Y) adalah sebesar 0,000. Sedangkan koefisien determinasinya sebesar 0.317 menunjukkan bahwa besarnya kontribusi minat belajar $\left(\mathrm{X}_{1}\right)$ penguasaan kosakata $\left(\mathrm{X}_{2}\right)$ secara bersama-sama terhadap kemampuan menulis teks deskripsi(Y) adalah sebesar $31,7 \%$, sisanya $(68,3 \%)$ karena pengaruh faktor lain.

Sedangkan untuk pengujian hipotesis melalui analisis regresi diperoleh hasil perhitungan terlihat Tabel 2. diperoleh persamaan garis regresi yang merepresentasikan pengaruh variabel $\mathrm{X}_{1}$ dan $\mathrm{X}_{2}$ terhadap variabel $\mathrm{Y}$, yaitu $\widehat{\mathbf{Y}}=\mathbf{1 8 , 7 5 7}+\mathbf{0 , 2 3 6} \mathrm{X}_{\mathbf{1}}+\mathbf{0 , 4 0 2} \mathrm{X}_{2}$.Sedangkan pengujian signifikansi garis regresi tersebut adalah dengan memperhatikan hasil perhitungan yang ada pada Tabel 3. Menurut ketentuan yang ada, kriteria signifikansi regresi tersebut adalah "jika $\mathbf{S i g}<$ 0.05 maka $\mathrm{H}_{0}$ ditolak" atau "jika $\mathbf{F}_{\text {hitung }}>\mathbf{F}_{\text {tabel }}$ maka $\mathrm{H}_{0}$ ditolak", yang berarti bahwa koefisien regresi tersebut signifikan, dengan kata lain terdapat pengaruh yang signifikan variabel bebas $X_{1}$ dan $X_{2}$ terhadap variabel terikat $Y$. Sedangkan nilai $\mathbf{F}_{\text {tabel }}$ adalah nilai tabel distribusi $\mathbf{F}$ untuk taraf nyata 5\% dengan derajat pembilang $(\mathrm{k})=2$ dan derajat penyebut $(\mathrm{n}-\mathrm{k}-1)=85$ dimana $\mathrm{n}$ adalah banyaknya responden, dan $\mathrm{k}$ adalah banyaknya variabel bebas. Dari Tabel 3. terlihat bahwa nilai Sig $=$ $0.000<0.05$ dan $\mathbf{F}_{\text {hitung }}=19,694>\mathbf{F}_{\text {tabel }}=3,100$ maka $\mathrm{H}_{0}$ "ditolak" yang berarti dapat disimpulkan bahwa koefisien regresi tersebut signifikan. Dengan kata lain 
bahwaterdapat pengaruh yangsignifikan pada variabel bebas penguasaan kosakata $\left(\mathrm{X}_{1}\right)$ Minat Belajar $\left(\mathrm{X}_{2}\right)$ secara bersama-sama terhadap Kemampuan Menulis Teks Deskripsi(Y).

Penguasaan kosakatadan Minat Belajar sangat berpengaruh terhadap proses belajar siswa dalam Kemampuan Menulis Teks Deskripsi.Minat Belajartidak hanya bermakna bagi proses belajar siswa, tetapi juga memberikan umpan balik bagi pencapaian tujuan-tujuan yang diharapkan. Selain itu dapat digunakan untuk mengukur sampai sejauh mana keefektifan pengalaman belajar siswa.Berdasarkan temuan ini menunjukkan bahwa peningkatan Kemampuan Menulis Teks Deskripsidapat dilakukan dengan memperbanyak penguasaan kosakatadan menumbuhkan Minat Belajar. Dengan kata lain, penelitian ini menunjukkan bahwa peningkatan Kemampuan Menulis Teks Deskripsisecara bersama-sama oleh penguasaan kosakatadanMinat Belajar.

Untuk hasil uji hipotesis 2 maka lihat pada tabel 3 diperoleh bahwa nilai Sig $=0.000<0.05$ dan thitung $=4,324$ maka $\mathrm{H} 0$ di tolak yang berarti terdapat pengaruh yang signifikan variabel bebas X1 (penguasaan kosakata) terhadap variabel terikat Y (Kemampuan Menulis Teks Deskripsi).

Seseorang yang memiliki penguasaan kosa kata yang baiktidak akan memiliki hambatan dalam berkomunikasi dengan orang lain dan tidak akan menemui kesulitan berarti saat harus memahami isi yang terkandung dalam sebuah bacaan. Keraf (1996: 24) merumuskan pengertian kosakata, yakni keseluruhan kata yang dimiliki suatu bahasa. Kosa kata tidak lain adalah daftar kata yang segera akan diketahui artinya bila didengarkan kembali walaupun jarang ataupun tidak pernah digunakan lagi dalam percakapan atau tulisan kita sendiri. Perbendaharaan kata seseorang adalah keseluruhan kata yang berada dalam ingatan seseorang yang akan menimbulkan reaksi bila didengar atau dibaca.penguasaan kosakata yang besar cenderung memiliki kemampuan menulis teks deskripsi lebih tinggi, sebaliknya penguasaan kosakata yang kurang cenderung memiliki kemampuan menulis teks deskripsi lebih rendah. Maka apabila seorang siswa mempunyai penguasaan kosakatayang besar itulah yang memungkinkan siswa tadi untuk belajar lebih giat, dan akhirnya mencapai prestasi yang tinggi.

Untuk hasil uji hipotesis 3 maka lihat pada tabel 4 diperoleh bahwa nilai Sig $=0.000<0.05$ dan $\mathbf{t}_{\text {hitung }}=4,761$ maka $\mathrm{H}_{0}$ ditolakyang berarti terdapat pengaruh yang signifikan variabel bebas $\mathrm{X}_{2}$ (Minat Belajar) terhadap variabel terikat $\mathrm{Y}$ (Kemampuan Menulis Teks Deskripsi).Minat Belajar merupakan kalimat yang terdiri dari dua kata yaitu "minat" dan "membaca".Oleh sebab itu, penulis akan kemukakan beberapa pengertian tentang "minat" antara lain adalah: Slameto menyatakan bahwa minat adalah "suatu rasa suka dan rasaketerikatan pada suatu hal atau aktivitas tanpa ada yang menyuruh".

Menurut Slameto (dalam Hartinah dan Abdullah, 2018: 129) minat merupakan rasa suka atau tertarik terhadap suatu aktivitas atau kegiatan tanpa ada unsur paksaan. Pada dasarnya, minat merupakan berterimanya antara diri sendiri dengan dunia luar. Semakin kuat hubungan tersebut, semakin kuat minat. Mahfudh Salahudin dalam Mahfudh menyatakan bahwa minat adalah "menentukan suatu sikap yang menyebabkan seseorang aktif dalam suatu pekerjaan atau perhatian yang mengandung unsur-unsur perasaan" (Yasinta dan Fernandes, 2020: 171) . Dari 
beberapa pendapat di atas dapat disimpulkan bahwa minat merupakan sumber motivasi yang dapat mendorong seseorang untuk belajar. Berdasarkan temuan penelitian telah dibuktikan bahwa terdapat pengaruh minat belajar terhadap kemampuan menulis teks deskripsi siswa MTs Swasta di Jakarta Selatan.Siswa yang memiliki minat belajaryang tinggi cenderung memiliki kemampuan menulis teks deskripsi lebih tinggi. Sebaliknya siswa yang memiliki tingkat minat belajar yang rendah cenderung memiliki kemampuan menulis teks deskripsi lebih rendah juga..

\section{SIMPULAN}

Berdasarkan hasil analisis data pada tabel 1, 2, dan 3 di atas dapat disimpulkan bahwa terdapat pengaruh yang signifikan penguasaan kosakata dan minat belajar secara bersama-sama terhadap kemampuan menulis teks deskripsi pada siswa MTs Swasta di Jakarta Selatan. Hal ini dibuktikan dengan perolehan nilai Sig $=0.000<0.05$ dan $\mathbf{F}_{\text {hitung }}=19,694$. Terdapat pengaruh yang signifikan penguasaan kosakata terhadap kemampuan menulis teks deskripsi pada siswa MTs Swasta di Jakarta Selatan. Hal ini dibuktikan dengan perolehan nilai $\mathbf{S i g} \boldsymbol{.}=0.018<$ 0.05 dan $\mathbf{t}_{\text {hitung }}=2,408$. Terdapat pengaruh yang signifikan minat belajar terhadap kemampuan menulis teks deskripsi pada siswa MTs Swasta di Jakarta Selatan. Hal ini dibuktikan dengan perolehan nilai $\mathbf{S i g}=0.000<0.05$ dan $\mathbf{t}_{\text {hitung }}=4,503$. Hasil penelitian menunjukan bahwa secara umum siswa yang mempunyai minat belajar dan penguasaan kosakata yang tinggi akan memiliki kemampuan menulis teks deskripsi yang lebih baik daripada siswa yang penguasaan kosakata yang rendah atau siswa yang biasa-biasa saja.

\section{DAFTAR PUSTAKA}

Finozza, L. (2009). Komposisi Bahasa Indonesia untuk mahasiswa nonjurusan bahasa. Jakarta: Diksi Insan Mulia.

Hartinah, H., \& Abdullah, S. I. (2019). Pengaruh minat baca dan persepsi atas perpustakaan sekolah terhadap keterampilan menulis narasi. Diskursus: Jurnal Pendidikan Bahasa Indonesia, 1(02), 127-135.

Kridalaksana, H. (2008). Kamus linguistik. Edisi Keempat. Jakarta: Gramedia Pustaka Umum.

Nurgiyantoro. B. (2001). Penilaian dalam pengajaran bahasa dan sastra. Yogyakarta: PT. BPFE

Rofiee uddin, A., \& Zuhdi (1999). Pendidikan bahasa dan sastra Indonesia di kelas tinggi. Malang: Universitas Negeri Malang.

Sardiman. (2007). Interaksi dan motivasi belajar-mengajar.Jakarta: Raja Grafindo Persada

Suryabrata, S. (1993). Psikologi pendidikan. Jakarta: Rajawali.

Tarigan, H (2008). Menulis sebagai suatu keterampilan berbahasa. Bandung: Angkasa

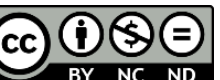

Creative Commons Attribution-NonCommercial-NoDerivatives 4.0 International License 
Diskursus: Jurnal Pendidikan Bahasa Indonesia

Vol. 3, No. 1, April 2020, pp. 55-62

p-ISSN: 2615-4935

e-ISSN: $2615-4943$

Yasinta, Y., \& Fernandes, R. (2020). Dampak penggunaan jejaring sosial geschool terhadap minat belajar. Jurnal Sikola: Jurnal Kajian Pendidikan dan Pembelajaran, 1(3), 168-174. 